\title{
Morphologic characterization of spiked pepper's germplasm
}

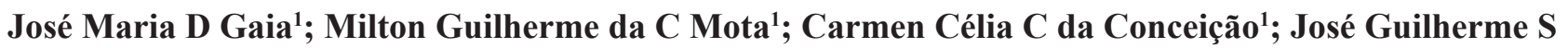 \\ Maia $^{2}$ \\ ${ }^{1}$ UFRA-ICA, C. Postal 917, 66077-530 Belém-PA; josegaia@globo.com; ${ }^{2}$ UFPA, C. Postal 479, 66075-110 Belém-PA
}

\begin{abstract}
Spiked pepper is a plant species with properties that allow the development of natural agrochemicals and medicines, showing large potential of use by humanity. With aim to ascertain the phenotypical variability, 41 parentals were analyzed, sampled in the States of Pará and Amazonas. Principal Component analysis and Jolliffe's criterion were utilized for discarding of variables, subsidized by the Pearson's Correlation. It took seven components to explain $80 \%$ of the variation. The essential oil yield and number of leaves per branch were suggested to be discarded because they are the characteristics that have contributed least to the total variance. The $3 \mathrm{D}$ scatter diagram constituted a relatively homogeneous and continuous clustering, identifing a divergent pair: PA-020 (Marabá-PA) and PA-035 (Santa Isabel-PA). The analyzed traits have variability potentially able to discriminate the parentals, whereas $83.3 \%$ of such traits can be used for this purpose. The divergent genotypes identified on 3D scatter diagram analysis can be used in breeding programs for the development of superior genotypes. A comparison with preexisting molecular data of some genotypes permited to conclude that there was one certain agreement degree between morphological and molecular characterizations and that molecular characterization presented higher discriminatory power, using a smaller number of genotypes, identifying dissimilar genotypes and clusters, although analyzed by different multivariate statistic methods.
\end{abstract}

Keywords: Piper aduncum L., agromorphological traits, parentals, genotypes, essential oil, dillapiole.

\begin{abstract}
RESUMO
Caracterização morfológica de germoplasma de Pimentade-Macaco

Pimenta-de-macaco é uma espécie que possui propriedades que permitem o desenvolvimento de defensivos agrícolas naturais e medicamentos, apresentando, portanto, grande potencial de uso pela humanidade. Com o objetivo de determinar a variabilidade fenotípica, foram estudadas 41 matrizes amostradas nos Estados do Pará e Amazonas. Utilizou-se análises de componentes principais e critério de Jolliffe para descarte de variáveis, subsidiado pela correlação de Pearson. Foram necessários sete componentes para explicar $80 \%$ da variação. $\mathrm{O}$ rendimento de óleo essencial e o número de folhas por ramo foram sugeridos para descarte por serem as características que menos contribuíram para a variação total. A dispersão gráfica 3D formou um grupo relativamente homogêneo e contínuo, permitindo identificar um par divergente: PA-020 (Marabá-PA) e PA-035 (Santa Isabel-PA). Concluiu-se que os caracteres analisados possuem variabilidade potencialmente capaz de discriminar as matrizes, com $83,3 \%$ de tais caracteres podendo ser utilizados para este objetivo. Os genótipos divergentes, identificados na análise gráfica $3 \mathrm{D}$, podem ser usados em programas de melhoramento para obtenção de genótipos superiores. A comparação com os dados moleculares, previamente existentes, de alguns desses genótipos permite concluir, também, que a caracterização molecular, apesar de apresentar certo grau de concordância com a caracterização morfológica, teve maior poder discriminatório, utilizando um menor número de genótipos e procedências, identificando grupos dissimilares e genótipos divergentes, embora analisado por método estatístico multivariado diferente.
\end{abstract}

Palavras-chave: Piper aduncum L., caracteres morfoagronômicos, matrizes, genótipos, óleo essencial, dilapiol.

(Recebido para publicação em 24 de novembro de 2009; aceito em 11 de dezembro de 2010) (Received on November 24, 2009; accepted on December 11, 2010)

$\mathrm{S}_{\mathrm{r}}^{\mathrm{p}}$ piked pepper is an aromatic species found in the Brazilian Amazon region, which has great potential for economic exploitation, due to the properties of its essential oil, which is useful to agriculture and human health. It has a yield that varies from $1.2 \%$ to $3.4 \%$, and its major constituent is dillapiole, which can be as much as $97 \%$ of the oil (Maia et al., 1998). Several studies have demonstrated the fungicidal, bactericidal and insecticidal properties attributed to dillapiole (Bastos, 1997; Bastos \& Albuquerque,
2004; Fazolin et al., 2007) which, when converted to natural defenses, can reduce environmental impacts in agriculture through the use of such defenses, and can also be used in the development of phytotherapeutic agents and conventional pharmaceuticals, among others.

Studies on the diversity of spiked pepper utilizing RAPD markers have shown groupings related to geographic origin (Gaia et al., 2004). Studies were carried out in long pepper (Piper hispidinervium C. DC.) on the genetic structure and reproductive system (Wadt \& Kageyama, 2004), contributing to our knowledge of the variability of these species, which are very similar from a morphobotanical point of view. In the genus Capsicum, the phenotypic variability between 48 accessions of pepper (C. annuиm L.) was estimated to be about $54 \%$, concentrated in the first six principal components, by the analysis of 67 morphoagronomic traits, where the diversity displayed has potential for agronomic improvement, since the levels of genetic diversity 
detected increase the efficiency of efforts to improve the species (Bozokalfa et al., 2009).

The morphologic characterization of germplasm is a basic requisite for determining the genetic variability of germplasm collections and thereby makes it possible to use them in breeding programs. The morphologic traits, however, are often polygenic and strongly influenced by the environment, and this makes selection for breeding dependent on the growth and development of the plants, which increases the time and cost necessary for the characterization of the accessions (Souza \& Contel, 2001). This does not occur with molecular markers, which are free from environmental influence and can contribute, together with morphoagronomic information, to a better understanding of the diversity present (Sudre et al., 2010).

However, for Capsicum annuum L., a solanaceous species, it has been reported that morphologic and AFLP molecular markers generally separate pepper genotypes in accordance with fruit characteristics, showing a significant positive correlation between morphologic markers and AFLP markers. This indicates that the distance between AFLP markers tends to reflect the distance between morphologic markers, so that in the discrimination of genotypes, one can choose to use one or the other (Bozokalfa et al., 2009). This information can be considered helpful in studies of spiked pepper, because in many cases, there is correlation and agreement between morphologic and molecular markers, as observed in potato, Solanum tuberosum (Spooner et al., 2005).

The aim of this work was to evaluate and quantify the phenotypic variability of spiked pepper genotypes collected in the Brazilian Amazon region, by studying the morphoagronomic traits, for utilization in future breeding programs.

\section{MATERIAL AND METHODS}

Cuttings, leaves and fine branches were collected from 41 parentals. The plants were sampled in environments of natural occurrence of spiked pepper in nine municipalities and five mesoregions in the States of Pará and Amazonas (Table 1). The cuttings, after chemical treatment, were propagated and the plants were maintained in the Germplasm Bank of the Rural Federal University of Amazonia (UFRA). The leaves and twigs were analyzed with respect to levels of essential oil and dillapiole, in the Phytochemical Laboratory of the Museu Paráense Emilio Goeldi (MPEG), in Belem, Pará State.

During the collections, we obtained measurements of nine morphologic traits: 1) mean number of leaves per branch (NFR), obtained from five branches of the middle part of the plant; 2) leaf length $(C F)$, size of the fifth leaf counting from the insertion point of the fifth branch, which in turn begins at the mid-height of the plant; 3) leaf width (LF), obtained from the fifth leaf also counting from the insertion point of the fifth branch, which in turn begins at the mid-height of the plant; 4) circumference of the oldest branch (CRV), considered the most developed, in thickness and size, from the stem about $20 \mathrm{~cm}$ from the ground; 5) plant height (AP), measured from the ground to highest point of the plant; 6) total number of orthotropic branches (NRO), obtained by simple counting; 7) total number of plagiotropic branches (NRP), also obtained by simple counting; 8) internode length (CEN), obtained at $50 \mathrm{~cm}$ from the ground; 9) number of spikes per branch (NER), corresponding to the mean of five branches obtained randomly. We also evaluated three agronomic traits: 1) yield of essential oil (RO) (\%), extracted from $100 \mathrm{~g}$ of dried leaves left in a tray, in an environment with dehumidified refrigerated air, dim light and a temperature around $25^{\circ} \mathrm{C}$, for seven days; 2) dillapiole level (TD) (\%) is the essential oil, which was extracted from $100 \mathrm{~g}$ of dry matter (leaves), dried in the same way to obtain RO; and 3) production of dillapiole (PD) (g), mass of dillapiole corresponding to the level (dillapiole) in $100 \mathrm{~g}$ of essential oil, considering a density of 1 for the oil.

For analysis of morphologic variability, the means of each trait were determined, per parental, which were analyzed by principal components. To eliminate the effect of different metric scales in the calculation of the principal components, the means were standardized by the following formula: $\mathrm{x}_{\mathrm{i}}=\mathrm{X}_{\mathrm{i}} / \mathrm{S}_{\mathrm{x}}$, where $\mathrm{x}_{\mathrm{i}}$, represents the standardized means, $X_{i}$ the means of the traits and $\mathrm{S}_{\mathrm{x}}$ the respective standard deviations. The identification of redundant traits was done by the utilization of the criterion proposed by Jolliffe (1972, 1973), which advocates beginning with components that show the smallest eigenvalues up to the limit of 0.70 , associated with greater eigenvectors, in the respective components, aided by Pearson's correlation. Three-dimensional scatter plot analysis was also utilized, which is recommended for complementary studies based on principal components in cases in which the first two components do not concentrate at least $80 \%$ of the variability (Cruz \& Regazzi, 2001). The calculations were carried out in the program GENES (Cruz, 2006).

\section{RESULTS AND DISCUSSION}

The estimates of the eigenvalues appeared partitioned in the component vectors, requiring seven components to explain $80 \%$ of the total variance (Table 2); for there to be divergence between the genotype groups, it is expected that the first two components explain at least $80 \%$ of the total variance (Cruz \& Regazzi, 2001). In the present study, the first two principal components explained only $33.8 \%$ of the total variation. Similar results were also obtained in pepper, where the first components explained only $24.8 \%$ of the total variation, approaching the expected value only in the tenth component, when it reached $71.5 \%$ of the variation (Bozokalfa et al., 2009).

On applying the criterion of discarding variables proposed by Jolliffe, the following were detected as recommended for discard: i) the yield of essential oil, in the last vector component (CP12), which showed a variance $(\mathrm{V})$ of 0.055 and associated weighting coefficient (CDP) of 0.536 
Table 1. List of spiked pepper's parentals utilized on germplasm morphologic characterization sampled from Brazilian Amazon (germoplasma utilizado na caracterização morfológica de pimenta-de-macaco coletado na Amazônia brasileira). Belém, UFRA, 2008.

\begin{tabular}{llllllll}
\hline Sequence & Parental & Municipality & MR & Sequence & Parental & Municipality & MR \\
\hline 1 & PA-001 & Manaus-AM & MAA & 22 & PA-021 & Marabá-PA & SUP \\
2 & PA-002 & Manaus-AM & MAA & 23 & PA-022 & Goianésia-PA & SUP \\
3 & PA-003/01 & Manaus-AM & MAA & 24 & PA-023 & Goianésia-PA & SUP \\
4 & PA-003/02 & Manaus-AM & MAA & 25 & PA-024 & Goianésia-PA & SUP \\
5 & PA-004 & Manaus-AM & MAA & 26 & PA-025 & Goianésia-PA & SUP \\
6 & PA-005 & Manaus-AM & MAA & 27 & PA-026 & Moju-PA & BAT \\
7 & PA-006 & Manaus-AM & MAA & 28 & PA-027 & Moju-PA & BAT \\
8 & PA-007 & Manaus-AM & MAA & 29 & PA-028 & Moju-PA & BAT \\
9 & PA-008 & Manaus-AM & MAA & 30 & PA-029 & Moju-PA & BAT \\
10 & PA-009/01 & Manaus-AM & MAA & 31 & PA-030 & Belém-PA & NEP \\
11 & PA-009/02 & Manaus-AM & MAA & 32 & PA-031 & Belém-PA & NEP \\
12 & PA-010 & Manaus-AM & MAA & 33 & PA-032 & Belém-PA & NEP \\
13 & PA-011 & Manaus-AM & MAA & 34 & PA-033 & Belém-PA & NEP \\
14 & PA-012 & Marabá-PA & SUP & 35 & PA-034 & Belém-PA & NEP \\
15 & PA-013 & Marabá-PA & SUP & 36 & PA-035 & Santa Isabel-PA & NEP \\
16 & PA-014 & Marabá-PA & SUP & 37 & PA-036 & Santa Isabel-PA & NEP \\
17 & PA-015 & Marabá-PA & SUP & 38 & PA-037 & Americano-PA & NEP \\
18 & PA-016 & Marabá-PA & SUP & 39 & PA-038 & Bonito-PA & NEP \\
19 & PA-018 & Marabá-PA & SUP & 40 & PA-039 & Bonito-PA & NEP \\
20 & PA-019 & Marabá-PA & SUP & 41 & PA-040 & Santarém Novo-PA & NEP \\
21 & PA-020 & Marabá-PA & SUP & & & & \\
\hline
\end{tabular}

$\mathrm{MR}=$ meso-region (mesorregião); MAA= Mean Amazon River from Amazon State (Médio Amazonas Amazonense); SUP= South of Pará State (Sul do Pará); BAT= Low Tocantins River from Pará State (Baixo Tocantins); NEP: Northeast of Pará State (Nordeste paraense).

as absolute value; ii) number of leaves per branch, in the component $\mathrm{CP} 11(\mathrm{~V}=$ 0.306 and $\mathrm{CDP}=0.597)$; iii) number of plagiotropic branches, in the component $\mathrm{CP} 10(\mathrm{~V}=0.488$ and $\mathrm{CDP}=0.457)$; and iv) leaf width, in the component CP9 $(\mathrm{V}=0.601$ and $\mathrm{CDP}=0.483)$. These variables, therefore, contributed the least to discriminating total variation (Table 2). The others showed values over 0.70 , corresponding to $83.33 \%$ of the traits studied and are potentially important in the composition of the variability of spiked pepper.

A significant correlation was determined in five pairs of traits, of which four involved traits recommended for discard (Table 3). The number of leaves per branch revealed a high correlation (0.503) with the production of dillapiole, with a probability of error of $1 \%$ ( $t$ test), where it was the only correlation above 0.50 , in absolute values. The correlation between yield of essential oil and internode length was also close to this value (0.496), also with a probability of error of $1 \%$. The yield of essential oil also correlated with the level of dillapiole (0.323), with a probability of error of $5 \%$, which in turn correlated with the production of dillapiole, at the same level of probability.

Combining the results generated by the application of Jolliffe's criterion with the information obtained by correlation analysis, we can propose for discard, with reduced risk of losing information, the traits yield of essential oil and number of leaves per branch, because according to Cruz \& Regazzi (2001), correlated traits imply redundant variables, and are therefore dispensable in the process of germplasm characterization. On the other hand, discarding the number of orthotropic branches and leaf width can cause loss of information, because they do not show either high or significant correlation with other traits.

Oliveira et al. (2006), in selecting descriptors for the characterization of accessions of açaí by Jolliffe's criterion, reanalysis and correlation, found that six of 28 descriptors were redundant (disposable) by the fact that these descriptors were significant and highly correlated with the others, kept for characterization. On the other hand, Arriel et al. (2000) determined two redundant traits out of the six studied in sesame (Sesamum indicum L.).

In general, there was no tendency of grouping in the scatter plot based on the first three principal components (Figure 1). However, some parentals stand out by being relatively separated from the whole, as in the case of points 30 (PA-029, Moju, lower Tocantins), and 36 (PA-035, Santa Isabel, northeastern Pará), in addition to point 21 (PA020, Marabá, southern Pará), which stands out because of the lower level of similarity. The parentals PA-020 and PA-035 were the most divergent. The others formed a single cluster 
Table 2. Assessments of the eigenvalues and eigenvectors associated to the principal components of spiked pepper's agromorphological traits (estimativas dos autovalores e autovetores associados aos componentes principais de caracteres morfoagronômicos em pimenta-de-macaco). Belém, UFRA, 2008.

\begin{tabular}{|c|c|c|c|c|c|c|c|c|c|c|c|c|c|c|c|}
\hline \multirow[b]{2}{*}{ CP } & \multicolumn{3}{|c|}{ Variance } & \multicolumn{12}{|c|}{ Weighting coefficient } \\
\hline & ATV & $\begin{array}{l}\text { VRE } \\
\text { (\%) }\end{array}$ & $\begin{array}{l}\text { VAC } \\
\text { (\%) }\end{array}$ & FR & $\mathbf{C F}$ & $\mathbf{L F}$ & CRV & AP & NRO & NRP & NER & CEN & RO & TD & PD \\
\hline P1 & 2.21 & 18.40 & 18.4 & & 0.30 & 1 & 0.14 & -0.15 & -0.04 & 3 & -0.35 & 0.42 & $-0.4 J$ & 0.21 & -0.10 \\
\hline $\mathrm{P} 2$ & 1.85 & 15.40 & 33 & 0.30 & -0.16 & 0.01 & -0.27 & 0.07 & -0.27 & 0.27 & -0.26 & 0.35 & -0.07 & -0.39 & 56 \\
\hline CP3 & 1.56 & 13.00 & 46 & 0.37 & -0.04 & 0.04 & 27 & -0.44 & 0.49 & -0.40 & -0.02 & 0.20 & -0.19 & 0.11 & 0.33 \\
\hline СP4 & 1.25 & 10.40 & 57 & 0.12 & 0.59 & -0.19 & -0.37 & -0.05 & -0.27 & -0.50 & 0.18 & 0.25 & 0.20 & -0.02 & -0.02 \\
\hline P5 & & & & & & & & & & & & & & 0 & \\
\hline CP6 & 0.98 & 8.21 & 75 & 0.27 & 0.14 & -0.33 & 0.37 & 0.60 & -0.06 & -0.05 & 0.33 & -0.13 & -0.37 & -0.02 & 0.18 \\
\hline CP7 & 0.80 & 6.70 & 81.8 & 0.33 & -0.20 & -0.18 & -0.01 & -0.14 & -0.46 & 0.02 & -0.18 & -0.21 & 0.10 & 0.70 & 0.10 \\
\hline CP8 & 0.74 & 6.15 & 88.0 & -0.16 & -0.39 & -0.32 & -0.21 & -0.28 & -0.03 & 0.15 & 0.71 & 0.23 & -0.09 & 0.07 & 0.05 \\
\hline СР9 & 0.61 & 5.00 & 92. & 0.23 & -0.30 & -0.48 & -0.24 & 0.33 & 0.42 & -0.07 & -0.26 & 0.22 & 0.25 & 0.03 & -0.32 \\
\hline CP10 & 0.49 & 4.07 & 97. & 0.09 & 0.43 & -0.17 & -0.35 & -0.10 & 0.43 & 0.46 & 0.06 & -0.39 & 0.05 & 0.13 & 0.28 \\
\hline CP11 & 0.31 & 2.55 & 99. & -0.60 & -0.17 & -0.21 & -0.07 & 0.18 & 0.07 & -0.39 & -0.16 & -0.18 & 0.12 & 0.08 & 0.55 \\
\hline CP12 & 0.06 & 0.46 & 100.0 & 0.08 & -0.15 & -0.21 & -0.32 & -0.24 & -0.10 & -0.25 & -0.17 & -0.47 & -0.54 & -0.33 & -0.21 \\
\hline
\end{tabular}

CP: Principal component (componente principal); ATV: eigenvalues (autovalores); VRE: relative variance (variância relativa); VAC: accumulated variance (variância acumulada); NFR: number of leaves per branch (número de folhas por ramo); CF: leaf length, cm (comprimento da folha, cm); LF: leaf width, cm (largura da folha, cm); CRV: circumference of the oldest branch, cm (circunferência do ramo mais velho, $\mathrm{cm}$ ); AP: plant height, $\mathrm{m}$ (altura da planta, m); NRO: number of orthotropic branches (número de ramos ortotrópicos); NRP: number of plagiotropic branches (número de ramos plagiotrópicos); NER: number of spikes per branch (número de espigas por ramo); CEN: internode length, cm (comprimento do entrenó, cm); RO: essential oil yield, \% (rendimento de óleo essencial, \%); TD: dillapiole content, \%) (teor de dilapiol, \%); PD: dillapiole yield, g (produção de dilapiol, g).

continuously distributed in space, with high morphological similarity, but showed a sector (to the right of the basal plane) with greater concentration of parentals, where it can be considered a subgroup.

It was also noted that in relation to the lateral and bottom planes, only parental 36 (PA-035, Santa Isabel-PA) was above the mean; parental 37 (PA036, Santa Isabel-PA) was below, but very close to the mean. Appearing at the extreme opposite were parentals 21 (PA-020, Marabá-PA), 24 (PA-023, Goianesia-PA), 33 (PA-032, BelemPA) and 35 (PA-034, Belem-PA) and others not clearly perceivable, present in the subgroup of concentration, to the right of the basal plane. Therefore, in relation to the mean, they showed partial divergence, the origin Santa Isabel-PA (parental most above the mean) with the origins of southern Pará (Marabá and Goianesia) and the origin Belem-PA.

Bento et al. (2007) found that the first three components explained $80 \%$ of the total variation in accessions of peppers, forming clearly two groups, while Arriel et al. (2000) complemented the analysis of principal components with a scatter plot, whose variance was partitioned in the first four components, without tendency of the formation of groups, but identifying divergent accessions, while Bozokalfa et al. (2009) did not distinguish divergent accessions in a 3D scatter plot, but divided the genotypes into seven groups, by the Ward criterion, utilizing data from principal components analysis.

The molecular characterization by RAPD analysis of 18 clones originating from these parentals, taken from five locations (Manaus, Marabá, Goianesia, Moju and Belem), resulted in 120 RAPD markers, which represented $90.83 \%$ polymorphism, forming four groups. The groups constituted by clones from the collection in Marabá-PA were of lesser similarity, and the group constituted by clones of Manaus-AM showed, in general, greater similarities, thereby being the most divergent groups, where there was a tendency of clones from the same origin (municipality, mesoregion or State) to form groups of similarity. This was observed for the clones from Manaus-AM, besides Marabá and Goianesia (southern Pará). The clones of Moju (lower Tocantins) and Belem (northern Pará), which clustered in the same group, did not follow this tendency (Gaia et al., 2004).

On comparing these results with the scatter plot of the genotypes (Figure 1 ), despite the differences between the statistical methods, as well as the number of taxonomic units utilized, the RAPD markers were found to have greater discriminatory power than the morphoagronomic traits, because the scatter plot (41 parentals $\mathrm{x}$ nine origins) yielded a continuous and relatively homogeneous grouping. On the other hand, in the RAPD analysis (18 clones $\mathrm{x}$ five origins), there was the formation of at least four groups.

On the other hand, the dissimilarity of some genotypes, such as those of Marabá and Goianesia, in southern Pará, observed in RAPD analysis, was also demonstrated in a scatter plot, despite the homogeneity of the cluster formed. Therefore, it can be 
Table 3. Assessments of the coefficient of phenotypic correlation between spiked pepper's agromorphological traits (estimativas dos coeficientes de correlação fenotípica entre caracteres morfoagronômicos de pimenta-de-macaco). Belém, UFRA, 2008.

\begin{tabular}{|c|c|c|c|c|c|c|c|c|c|c|c|c|}
\hline CRT & NFR & $\mathbf{C F}$ & LF & CRV & AP & NRO & NRP & NER & CEN & RO & TD & PD \\
\hline NFR & 1 & & & & & & & & & & & \\
\hline $\mathrm{CF}$ & -0.22 & 1 & & & & & & & & & & \\
\hline LF & 0.15 & -0.28 & 1 & & & & & & & & & \\
\hline CRV & -0.06 & 0.00 & -0.24 & 1 & & & & & & & & \\
\hline AP & 0.049 & -0.05 & 0.09 & -0.20 & 1 & & & & & & & \\
\hline NRO & 0.05 & -0.10 & 0.14 & 0.23 & -0.19 & 1 & & & & & & \\
\hline NRP & -0.28 & -0.19 & -0.16 & -0.04 & 0.11 & -0.24 & 1 & & & & & \\
\hline NER & 0.09 & -0.09 & 0.10 & -0.06 & 0.11 & 0.070 & -0.31 & 1 & & & & \\
\hline CEN & -0.06 & 0.17 & -0.28 & -0.20 & -0.21 & -0.07 & 0.044 & $-0.36^{*}$ & 1 & & & \\
\hline RO & 0.20 & -0.16 & 0.11 & -0.20 & -0.07 & -0.14 & -0.22 & 0.19 & $-0.50 * *$ & 1 & & \\
\hline TD & -0.16 & 0.09 & -0.07 & 0.05 & -0.12 & 0.12 & -0.15 & -0.03 & -0.08 & $-0.323^{*}$ & 1 & \\
\hline PD & $0.50^{* *}$ & -0.18 & 0.06 & -0.11 & -0.088 & -0.08 & 0.05 & -0.11 & 0.21 & -0.1414 & $-0.3149 *$ & 1 \\
\hline
\end{tabular}

$\mathrm{CRT}=$ traits (caracteres); NFR, CF, LF, CRV, AP, NRO, NRP, NER, CEN, RO, TD, PD, see Table 2 (vide Tabela 2); **,*Significant at 1\% and at $5 \%$ of probability, by the $\mathrm{t}$ test (significativo em $1 \%$ e $5 \%$ de probabilidade, pelo teste $\mathrm{t}$ ).

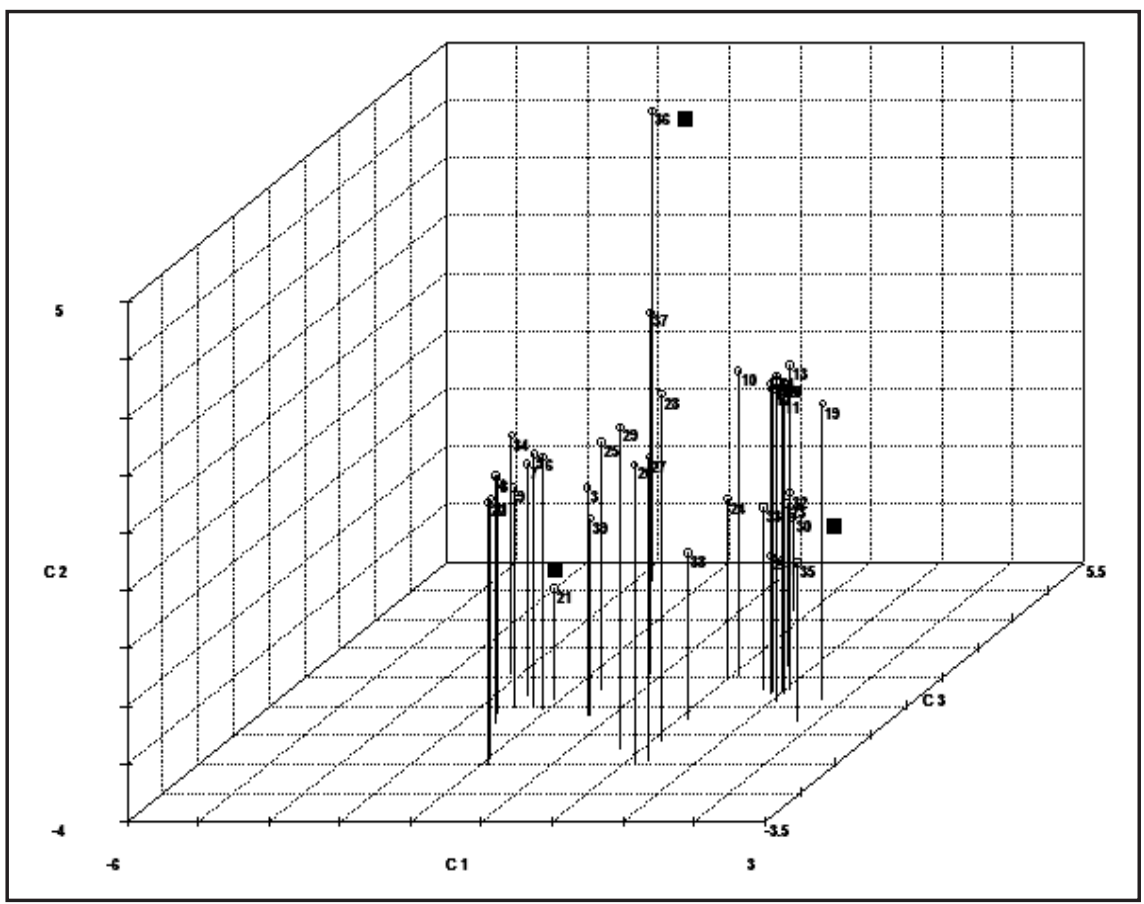

Figure 1. Relationship among spiked pepper's parentals based on agromorphological traits by mean $3 \mathrm{D}$ scatter diagram of the first principal components (dispersão gráfica 3D dos primeiros componentes principais com base em caracteres morfoagronômicos de pimentade-macaco). Belém, UFRA, 2008.

concluded that the two characterization models demonstrated a certain degree of concordance between the morphologic and molecular patterns. In pepper, there was a significant positive correlation between morphologic and AFLP molecular markers, as reported by
Bozokalfa et al. (2009).

We conclude that, except for the yield of essential oil and number of leaves per branch, the other morphoagronomic traits $(83.33 \%)$ show variability which can be potentially used to discriminate the genotypes studied.
The scatter plot of the first three principal components identified a pair of divergent parentals: PA-020 (Marabá-PA) and PA-035 (Santa IsabelPA), while a previous analysis using RAPD markers identified two clones from Marabá-PA with lesser similarity and four clones from Manaus-AM with greater similarity, constituting divergent genotypes and recommended for genetic improvement programs to utilize heterosis and obtain genotypes with segregation which will allow the selection of superior material.

Morphologic characterization showed a certain degree of concordance with molecular characterization, particularly in relation to material originated in southern Pará (Marabá and Goianesia), both dissimilar by the two characterization models. In spite of the differences in the statistical methods and the number of taxonomic units utilized, molecular characterization showed a greater discriminatory power, despite the availability of fewer genotypes and origins, identifying dissimilar groups and divergent genotypes.

\section{ACKNOWLEDGEMENTS}

The authors thank the following: PROBEM and CNPq for the resources made available for the collection and 
establishment of the Germplasm Bank of spiked pepper; Embrapa Amazonia Oriental, for permitting the use of their Molecular Markers Laboratory and some of the reagents; the researchers, staff and students who contributed to this work; and especially CAPES, for the scholarship awarded to the first author.

\section{REFERENCES}

ARRIEL NHC; SANTOS JW; MOREIRA JAN; NÓBREGA MBM; ANDRADE FP. 2000. Avaliação de descritores quantitativos na caracterização preliminar de germoplasma de gergelim (Sesamum indicum L.). Revista Brasileira de Oleaginosas e Fibrosas 4: 45-54.

BASTOS CN. 1997. Efeitos do óleo de Piper aduncum sobre Crinipellis perniciosa e outros fungos fitopatogênicos. Fitopatologia Brasileira 22: 441-443.

BASTOS CN; ALBUQUERQUE PSB. 2004 Efeito do óleo de Piper aduncum no controle pós-colheita de Colletotrichum musae em banana. Fitopatologia Brasileira 29: 555-557.

BENTO CS; SUDRE CP; RODRIGUES R; RIVA EM; PEREIRA MG. 2007. Descritores qualitativos e multicategóricos na estimativa da variabilidade fenotípica entre acessos de pimentas. Scientia Agraria 8: 149-156.

BOZOKALFA MK; ESIYOK D; TURHAN K. 2009. Patterns of phenotypic variation in a germplasm collection of pepper (Capsicum annuит L.) from Turkey. Spanish Journal of Agricultural Research 7: 83-95.

CRUZ CD. 2006. Programa Genes: Análise multivariada e simulação. Viçosa: Editora UFV. $175 p$.

CRUZ CD; REGAZZI AJ. 2001. Modelos biométricos aplicados ao melhoramento genético. 2ed. Viçosa: UFV. 390p.

FAZOLIN M; ESTRELA JLV; CATANI V; ALÉCIO MR; LIMA MS. 2007. Propriedade inseticida dos óleos essenciais de Piper hispidinervum C.DC.; Piper aduncum L. e Tanaecium nocturnum (Barb. Rodr.) Bur. \& K. Shum sobre Tenebrio molitor L., 1758. Ciência Agrotécnica 31: 113-120.

GAIA JMD; MOTA MGC; CONCEIÇÃO CCC; COSTA MR; MAIA JGS. 2004. Similaridade genética em populações naturais de pimentade-macaco por análise RAPD. Horticultura Brasileira 22: 686-689.

JOLLIFFE IT. 1972. Discarding variables in a principal component analysis; I. Artificial data. Applied Statistics 21: 160-173.

JOLLIFFE IT. 1973. Discarding variables in a principal component analysis; II. Real data. Applied Statistics 22: 21-31.

MAIA JGS; ZOGHBI MBG; ANDRADE EHA;
SANTOS AS; SILVA MHL; LUZ AIR; BASTOS CN. 1998. Constituents of the essential oil of Piper aduncum L. growing wild in the Amazon Region. Flavour and Fragrance Journal 13: 269-272.

OLIVEIRA MSP; FERREIRA DF; SANTOS JB. 2006. Seleção de descritores para caracterização de germoplasma de açaizeiro para produção de frutos. Pesquisa Agropecuária Brasileira 41: 1133-1140.

SOUZA RF; CONTEL EPB. 2001. Análise da variabilidade de alozimas em acessos e cultivares de girassol. Pesquisa Agropecuária Brasileira 36: 771-779.

SUDRÉ CP; GONCCALVES LSA; RODRIGUES R; AMARAL JÚNIOR AT; RIVA-SOUZA EM; BENTO, CS. 2010. Genetic variability in domesticated Capsicum spp as assessed by morphological and agronomic data in mixed statistical analysis. Genetics and Molecular Research, 9: 283-294.

SPOONER DM; MCLEAN K; RAMSAY G; WAUGH R; BRYAN GJ. 2005. A single domestication for potato based on multilocus amplified fragment length polymorphism genotyping. Proceedings National Academy Science, 102: 14694-14699.

WADT LHO; KAGEYAMA PY. 2004. Estrutura genética e sistema de acasalamento de Piper hispidinervium. Pesquisa Agropecuária Brasileira 39: 151-157. 